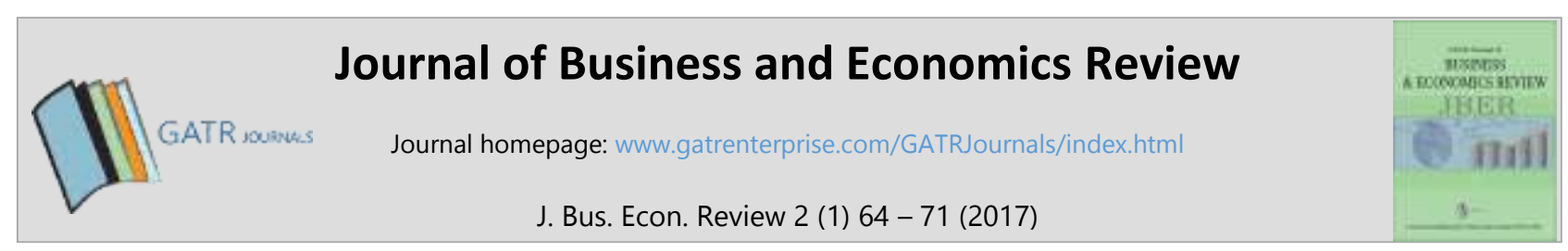

\title{
Political Communication Factors Affecting University Students' Political Participation
}

\author{
Kritiya Rujichok $^{1 *}$ and Sudithinee Obayavath ${ }^{2}$ \\ ${ }^{1}$ Nakhon Pathom Rajabhat University, Nakhon Pathom, Thailand \\ ${ }^{2}$ Sukhothai ThamathiratOpen University, Bangkok, Thailand
}

\begin{abstract}
Objective - The purposes of this research were to examine and study political communication factors affecting university students' political participation.

Methodology/Technique - The population was 2,613 university students from all over Thailand. Quantitative methodology was applied to survey students' opinions. The research instrument was a questionnaire. The statistics used for data analysis were percentage, mean, standard deviation and factor analysis. The factors affecting political participation were analyzed and used to find an effective strategy to promote political participation.

Findings - The research results showed that the factors affecting knowledge building in politics were family, university and classmates. Students' political decision making was based on their role models, e.g. idols, actors and musicians. The students did not agree with vote buying; however, they could not stop family or community leaders from doing it because of the seniority-based culture.
\end{abstract}

Novelty - The results provide suggested guidelines for developing students' political participation.

Type of Paper: Empirical

Keywords: Political Communication; Student Political Participation; Political Attitude; Political Knowledge; Political Public Consciousness.

JEL Classification: D83, H10

\section{Introduction}

Young adults, age 18-25, were given the right to vote in elections in the Constitution of the Kingdom of Thailand B.E. 2540 (1997). The organizations responsible for voting have tried to promote the awareness of exercising this right to young people in Bangkok and other provinces by a variety of means. Moreover, the promotion plans have been adjusted regularly to suit political situations.

Formerly, the government gave great importance to the campaign for encouraging people to exercise their voting rights. The results were shown in the increase of voter turnout each year to a peak of around 75 percent. However, the voting statistics from 2011 showed that while the overall turnout was 74.49 percent,

* Paper Info: Received: January 20, 2017

Accepted: March 15, 2017

* Corresponding author:

E-mail: kkritiya2014@gmail.com

Affiliation: Nakhon Pathom Rajabhat University, Thailand. 
only about 40 percent of the young adults who were eligible voters exercised their right to vote. One of the main reasons for not going to vote was they were not paying attention to current situations in society or the country; they primarily focused on their own lives.

In contrast, according to the Bangkok Poll conducted by the Bangkok University Research Center which surveyed the awareness of voting among the youth in the general election on February 6, 2013, most young people followed election news and intended to exercise their right to vote. They considered the election as a duty; however, they did not see the connection between voting and themselves. For those who did not go to vote, they had reasons such as having other errands to do, feeling bored with politics, not having a preferred candidate and being unable to take leave from work.

Additionally, most young adults had a candidate in mind and gave importance to policies and visions of political parties and candidates. They had an understanding of the voting process and election systems. Young people at the age of 25 gave the highest importance to the election compared to other groups.

Apart from the campaigns for voting promotion by related organizations, there were researchers who studied the political participation of students. Tossapon (2013) examined the level of political participation of Siam University students. Factors relating to the political participation of the students were identified. Moreover, guidelines for developing political participation were suggested. It was found that family income, information reception behavior and political behavior of students' guardians had positive relations to the level of students' political participation. As for guidelines, it was suggested that more public relations about political participation should be done.

Many government organizations also think that a project to develop the political participation process among the youth in universities, a potentially powerful group in the country, should be proposed.

In addition, the research applied the theoretical concepts and studies related to the approaches to analyzing political communication factors that affect university students' political participation, including the political communication concept, public consciousness concept, knowledge management concept and rational choice theory.

The political communication concept was applied as a framework to study the effect of the political communication process on university students' political participation, including their consideration of political issues and/or decision to participate in political discussions to exchange ideas, attitudes, and experiences with each other. The purpose of political communication is to encourage interaction between members of political groups in society. For the process of political communication, the group members use mass media for exchanging ideas, attitudes, and experiences with content concerning political items.

Deutsch (1953) framed the political communication concept using the idea that political participation is a significant concept of a political system covering the communication network system. The network system can link other networks as two-way communication in which the communicators can transmit data, give feedback to each group, exchange ideas and encourage political actions in the same or different communication line. The concept of political communication is the foundation that leads to communication factors concerning political communication such as data factors, the channel of communication factors and receiver factors.

Another important element which explains the political communication factors affecting university student political participation is political participation which can be at different levels of individuals as well as communication groups. Walter and Wilson (1998) studied and divided the extent of political participation into five levels.

The first level is pluralist political participation. This includes students who want to join all kinds of political activities, such as being a registered member of a political party, helping a politician to announce a political campaign, speaking on stage at political events, participating in political rallies and so on. In the future, these students are likely to be political candidates. 
The second level is direct political participation. It means students want to participate in the political activities that they are interested in, such as joining a protest, electing a candidate and sharing their political viewpoints in public. However, they do not want to be a registered member of a political party.

The third level is semi-direct political participation. For instance, students often join political activities, vote for candidates in elections and like to share their political views in public, in party meetings and with their friends and family.

The fourth level is also indirect political participation, for example, students who sometimes want to join political party activities, attend party meetings and vote for candidates in elections. Students will also sometimes share their political opinions in public and/or with their friends and family but not in party meetings.

Lastly, the fifth level is indirect political participation, for example, students who sometimes want to join political party activities and attend party meetings. It is different from the fourth level because they share their political ideas with their friends and family but not in public or in party meetings.

For this research, concepts of students' political participation were applied to develop factors to build a model of student political participation in Thailand at the present time as well as to determine the factors which influence and impact the model.

Moreover, the researcher reviewed rational choice theory to identify political communication factors and analyze their effects on university students' political participation. The rational choice theory, which is also known as a choice theory or rational action theory, is a basic concept to define normal social and economic behavior.

Rational choice theory believes that an individual has a preferred choice and he/she has the right to express what they want. People will use information, future action, advantages and disadvantages to make reasonable decisions and select the best choice for themselves.

Hollis and Nell (1975) defined an idea of neo-classicism based on rational choice theory, including an analysis of neo-classical economics and an innovation of economic methodology. In neo-classicism, consumers' behaviors are considered to be unimportant and as a simplified explanation of revealed preference theory. The behaviors of marginality producers in the product and service markets depend on the improvement of consumers' simple behaviors.

Hollis and Nell (1975) also explored defective and perfect markets due to neo-classicalism included various markets. The results were implied as a reference to other markets. Moreover, they stated that econometric procedure can be concluded from issues arising from basic modifying models (Hollis \& Nell, 1975). Particularly, in this class of copies, typical behavior can be maximized, and logic is less important. Faults are found in it and then lead to failure.

The concept of rationality partially represented the modern capitalist humanity. The problem of the rational-actor theory is that person who campaigns for natural conservation has to face existing disagreement on insufficient resource and they have to focus on the establishment of modern commercial society, or something similar. However, this way of thinking overlooks the ways in which current capitalist society and community relations, in fact, originate the "rational". The known limitations of rational-actor theory-static worth, logical antinomies, weakness to the argument of infinite retreat, failure in progress a radical actual research program — can be pointed out.

Bourdieu (2008) also considered the rational choice theory as a cause of misunderstanding about the definition of the social function. Bourdieu claimed that social representatives do not think based on explicit rational and economic criteria. According to Bourdieu, social agent operation makes an implication of practical logic, useful sense and bodily natures. Social agents act following their "sensation for the willing".

Additionally, this research study also analyzed political participation theory and political attitudes as a frame to study the effect of political participation on university students. The concept of political participation has a relationship with six levels of political attitudes. The first level is interested in politics and a good political attitude and the second level is political party admiration. The third level is a belief in 
political self-efficacy and the fourth level is the consciousness in a duty of people in political participation. The fifth level is political understanding and the last level is a bad attitude towards political participation or a lack of faith in democracy and politicians (Sinsawasdi, 1980). Therefore, political attitude is a factor of political participation, which is a variable in this study.

Furthermore, the knowledge management concept is applied in this study. Knowledge management means a compilation of knowledge in government sectors that scatters in individuals and documents to develop a system. Members of organizations can access that knowledge and develop themselves to be knowledgeable people. It is also possible for them to apply the knowledge effectively and give their organization high competitiveness. There are two types of knowledge: 1) tacit knowledge and 2) explicit knowledge. Knowledge can also be divided into four levels: 1) know-what, 2) know-how, 3) know-why and 4) care-why.

Knowledge management should start from work or a work goal. The important goal is the implementation achievement. Knowledge management can be done by integrated implementation of the following process: 1) identifying knowledge needed or important to work or a group activity, 2) seeking for knowledge, 3) adapting or creating new body of knowledge suited for practical use, 4) applying knowledge in work, 5) sharing work experience or application and extracting knowledge assets and 6) recording knowledge assets or core competencies and developing them into knowledge sets which are more complete, prudent, connected and suitable for work in the future.

To effectively manage knowledge in an individual, it is necessary to study the framework of knowledge management. The Ishikawa diagram also called a fishbone diagram or tuna model, is a causal knowledge management diagram. It compares knowledge management to a fish comprised of three parts: head, body, and tail. Each part has different duties. Later, this model was developed into a tuna model. The concept is that each organization is composed of different subunits. Knowledge of each unit has to be adjusted to suit the company, and the heads of the fish should face the same direction. The examples of knowledge transfer are official orientations for new employees, organization libraries, and professional training programs and mentoring. Towards the end of the20th century, knowledge transfer was developed to a computer-based format for wide dissemination. This allowed knowledge-based technology, expert systems, and knowledge banks, which make knowledge transfer easier.

Regarding knowledge management in political participation, strategies for knowledge creation knowledge society building, as well as an understanding of knowledge and related context should be studied, as discussed in this research.

Furthermore, the researchers summarized of existing research on the subject and the related studies about political participation at the level of general public and students. It was mentioned in both Thai and foreign studies that overall students' political participation from 2011 to 2015 was at a moderate to low level as seen in the study by Pimsiri Khamsen (2015).

As for foreign research, social media, especially Facebook, had an effect on creating political participation both in countries with normal political situations, such as Canada, the USA and Pakistan and in countries with political unrest, such as in Romania. Burean, Badescu, and Gabriel (2014) claimed that online political activities accelerated distrust in institutions and motivated the youth to engage in demonstrations in Romania although the effects might be at a moderate level. In the study of Visser and Stolle (2014) in Canada, one out four of students participated in voting because of online campaigns only, while almost half of students went to vote from offline media, online media and Facebook. This showed that online media had a high effect on students' political participation.

Additionally, Shulman and Levine (2012) explained that being in a group had an important effect on the political participation of students in 32 universities in the United States of America. Norms at the group-level were predictive of political behaviors at the individual level. The frequency of political communication at the group- and individual-level explained increases in political normative perception. Furthermore, Hill and Lachelier's work (2014) confirmed that face-to-face communication could not mobilize voter turnout. 
In the research of Esaiasson, Gilljam and Persson (2014), it was found that students' faculty or field of study had positive effects on decisions about political participation and political reasoning. Political science students had more trust in and gave more credit to voting than students of law and mass media. The results also showed that political science students were more interested in participatory democratic ideals and more appreciative of representative democracy than the other two majors.

Additionally, it was found in other research studies that political attitudes of students or of others affect political participation levels. For example, a person who is interested in politics understands political participation and believes in a political system and its credibility as well as the political responsibility of people. As a result, these citizens participate more in politics. In comparison, those who have a bad feeling or a lack of faith in political systems and politicians avoid politics (Pichai, 2013).

To contribute to this goal and expand previous studies, this research study was conducted to focus on political communication factors affecting the political participation of students in universities throughout Thailand. The study encompassed universities in five regions around Thailand: Central, Southern, Eastern, North-Eastern and Northern. The sample group of university students in these regions that was used as a model can be expanded to other groups of students in these universities and other universities around Thailand in terms of encouraging political participation and emphasizing its importance. The research objectives were to study political communication factors affecting university students' political participation and to analyze political judgment methods resulting from political communication factors affecting university students' political participation. The research questions were to concern with what are the political communication factors affecting university students' political participation and what is the result in analyzing political judgment methods resulting from political communication factors affecting university students' political participation.

\section{Method}

In this study, data were collected from questionnaires from a total of 2,613 students from universities in Thailand. The sample was randomly selected from students in universities that represented five regions of Thailand: South, East, North, North-East and Central. The basic questions concerned the attitudes of students in terms of political socialization, political information exposure, political information perception, political knowledge, political and believable knowledge, political public consciousness and political participation. The data were analyzed for frequency and standard deviation using the SPSS program and factor analysis.

\section{Results}

The research results showed that out of the factors of political communication, the aspect of students' perception of political news they received overall was at the lowest level. The media students received information from with the highest average was radio and television, followed by online media; while the media with the lowest average was community or student leaders. The frequency of political opinion exchange generally was at the low level. The duration of opinion exchange was one to two days per week, followed by never exchanging opinions, and the lowest average was exchanging opinions almost every day.

Regarding content, students got benefits from political opinion exchange at the lowest level. The most common topics were political problems, followed by the general information. The topic with the lowest average was living guidelines.

Overall, the aspect of political informant and reliability was at the lowest level. The people who gave the most information were teachers/instructors, followed by family members; while the people with the least reliability were employers.

The students' political news perception was generally at a moderate level. They mostly received information from the Prime Minister Talks program broadcast through Radio Thailand, followed by listening 
to House of Representatives meetings on the radio; while listening to the weekly government policy and performance address was at the lowest level.

As for the effect of news perception on political participation, students received political news at a moderate level. They mostly got information from the Internet, received knowledge about the Thai political system outside of the classroom, and played roles in knowledge development with political groups.

The factors of students' news perception with the highest relationships were receiving knowledge to develop Thai politics to an industrialized country system and receiving knowledge about the modernization of politics. The second was the relationship between receiving knowledge about institution relationships and political processes and knowing about global political change and international political systems. The lowest relationship was between receiving political news from the Internet and knowing information about the Thai political system outside of the classroom.

After factor rotation, there was one group of political news reception factors with a high coefficient. It comprised 11 variables about information reception as follows: 1) political news reception from the Internet; 2) information reception about the Thai political system outside of the classroom; 3) knowledge about the new election system of Thailand; 4) knowledge about the and relationship of Thai political parties; 5) information about institution relationships and political processes; 6) knowledge about political communication processes; 7) information about global political change and international political systems; 8) knowledge about political leadership; 9) information about the political development of Thailand compared to industrialized countries; 10) information about the modernization of politics and 11) action in knowledge development in politics and political groups.

\section{Discussion and Conclusion}

The research results were in accordance with the former research studies. The factor influencing students' low participation in politics was low information perception. This was because students were not interested in politics. They thought politics was about power, chaos, conflicts and impossibility to make changes. This is inconsistent with the study of Nie, Powell, and Prewett (1969) who claimed that if people had less political news exposure, they would not be interested in political participation.

In terms of the results about students' political news reception from media, students all over the country received political news at the lowest level. However, this was not in accordance with the study of Wongboonngam and Thanyasiri (2011) about the political news reception of students in Rajamangala Institute of Technology in Bangkok. Most students of Rajamangala Institute of Technology in Bangkok followed political news at a high level. The group that students mostly conversed about politics with was friends, in accordance with Wongboonngam and Thanyasiri (2011). This is similar to the studies of Shulman and Levine, that revealed students' political participation in American universities. The frequency of news reception had a positive relationship with political participation. In cases where students frequently received political news, they were more conscious of political participation.

Students' political communication model was two-way communication. There was a communication network between opinion leaders, who were teachers and parents, and feedback. The response was an input factor of the communication process, causing information or data, and finally led to change in political behavior. This result was consistent with the political communication concepts of Karl W. Deutsch.

Additionally, students' political communication was the exchange of opinions, attitudes, and experience in politics in the form of personal media. Consequently, it led to political interaction between students and political members. This is in accordance with political the communication concept of Phrutthisan. The communication channels were informal communication, face-to-face, and communication through nonpolitical opinion leaders, for example, senior family members, according to the study of a political communication channel of Almond and Powell. However, there was no communication through political interest groups or political associations, which was political input communication. As for output communication, there was also no communication through government units or political leaders. 
In the aspect of news channels and quantity, students as information receivers thought that there was a large quantity of political news, but this did not affect students' news reception. The quantity and content did not match. The more news was published, the more content was distorted, according to communication mechanisms. This was incompliance with the limitation of political communication stated by Almond and Powell. It mentioned that political communication channel could cause content distortion with technique and sound quality.

The result of political news reception in cases where it did not match thoughts, beliefs or attitudes, students thought that politics was complicated, difficult and not interesting, so they did not pay attention and rejected news reception. This was consistent with Almond and Powell's receiver characteristics.

According to political communication media, university students communicated about politics through personal media. They talked with friends, family, and via online media. Especially, online media was very popular in times of political crisis or important events, such as an election or disclosure of political corruption, including political discussions among group members. This finding was compliance with the study of Ahmad and Sheikh (2013) about students' political participation in Panjab University. It showed that students at Panjab University used Facebook to express an opinion and discuss national issues. The issues were related to political participation and election turnout. Moreover, it was in accordance with Visser and Stolle's (2014) research about political participation model in general election campaign through online and offline media. The study pointed out that online students participated in online political participation more than those offline.

In conclusion, research results reveal that political communication factors affecting university students' political participation include political news exposure, political system, student knowledge, political communication process, information about global political change and international political system, student knowledge about political leaders, information about the political development of Thailand, information about modern politics and political behavior of political groups. The findings derived from analyzing factors affecting university students' political participation also indicate that students' political knowledge is relatively low thus affecting their interests in all political participation. The reasons for students' lack of interest in politics include their perception on politics as complicated, political benefits, and disconnected to their lives. Such factors signify negative consequences on their political participation.

Based on the research results it could be suggested that the political process and those involved construct strategic planning on public relations regarding project implementation to create more acquaintance among students which could lead them to more political participation unavoidably. Also, among the participation process strategies are, for instance, use of popular media among campaigners or use of influential groups as a medium in creating participation of students.

Additionally, to create political participation with the consideration of political communication factors, it is advisable to build an associate network for political participation. This is for powering political knowledge enhancement, as well as political participation. The group power will promote information receiving, monitoring, and activity attending, as well as affecting project success.

\section{References}

Ahmad, K. \& Sheikh, K. (2013, July-December). Social media and youth participatory politics: A study of university students. South Asian Studies Journal, 23, 263-275.

Aunmba, E. \& Carrillo.(ed.) (2005). Knowledge management in construction. Oxford: Blackwell.

Bourdieu, P. (2008). Political interventions: Social science and political action. London: Verso.

Burean, T., Badescu, \& Gabriel. (2014). Voice of discontent: Student protest participation in Romania. Political Science Department, Babes-Bolyai University: Cluj, Romania.

David, H. \& Paul, L.(2014,November). Can face-to-face mobilization boost student voter turnout? Results of a campus field experience. Journal of High Education Outreach and Engagement, 18, 61-72.

Deutsch, K.W. (1953). Nationalism and social communication: An inquiry into the foundations of nationality. Cambridge: Mass: Technology Press of Massachusetts Institute of Technology. 
Esaiasson, P., Gilljam, M. \& Persson, M. (2012, October). Which decision-making arrangements generate the strongest legitimacy beliefs? Evidence from a randomized field experiment. European Journal of Political Research, 51, 785-809.

Gabriel, A.\& Bingham, P. (1966). Comparative politics: A development approach. Boston: Little.

Hill, D., \& Lachelier, P. (2014). Can Face-to-Face Mobilization Boost Student Voter Turnout? Results of a Campus Field Experiment. Journal of Higher Education Outreach and Engagement, 18(1), 61-88.

Hollis, M., \& Nell, E. J. (1975). Rational Economic Man: A Philosophical Critique of Neoclassical Economies. Cambridge University Press.

Martin, H. \& Nell, E.J.(1975). Rational economic man: A philosophical critique of Neo-Classical economics. London: Cambridge University Press. neo-classical?

Sinsawasdi, N.(1980). Local leaders and community activeness: An empirical study of 40 Thai rural communities. Bangkok: Thammasat University.

Norman H. Nie, G. Bingham Powell, Jr. and Kenneth Prewitt.(1969). Social structure and political participation: Developmental relationships. The American Political Science Review, 63 (3), 808-832.

Ratnatilaka na Bhuket,P. (2013,October.-December).The social factors influencing Thai students' political participation. NIDA Development Journal, 53 (4) (18-30).

Khamsen, P.(2015). The influence of printed media on the political participation behaviors of Ramkhamhaeng University Students. Master's Thesis, Department of Political Science, Faculty of Political Science: Ramkhamhaeng University.

Phrutthisan, C.(2550). Political system: Introduction knowledge. Bangkok: Chulalongkorn University Press.

Satienene, C.(1997). Political communication and developed country. Bangkok: Chulalongorn UniversityPress.

Shulman, H. \& Levine, T. (2012, January). Exploring social norms as a group-level phenomenon: Do political participation norms exist and influence political participation on college campuses? Journal of Communication, 62 (3),532-552.

Tossapon, S.(2013). Developing Proactive Programs to Develop Civic Politics. Political Development Council Office. Bangkok: King Prajadhipok’ Institute.

Visser, Sara. \& Stolle, Dietlind. (2014). Spill-Over Effects Between Facebook and On/Off line Political Participation? Evidence from a Two-Wavw Panel Study. Journal of Information Technology \& Politics, Jul-Sep, Vol. 11 Issue 3, p.259-275.

Walter, R. \& Wilson, H. (1998). Postcolonial Theory of Modernism. University of Toronto Quarterly. Vol.67 Issue 2.1998, p.568-591.

Wongboonngam, A. \& Thanyasiri, D. (2554). Political information exposure, knowledge and political participation of Rajamangala University of Technology's students in Bangkok.Journal of Political Science, 2, 25-37. 